\title{
AJUBA Gene
}

National Cancer Institute

\section{Source}

National Cancer Institute. AJUBA Gene. NCI Thesaurus. Code C115436.

This gene plays a role in the assembly of protein complexes, which are involved in a number of cellular processes. 